\title{
NILAI-NILAI SISTEM PENGURUSAN KUALITI ISLAM BERASASKAN AL-QURAN DAN INTEGRASI ILMU SAINTIFIK*
}

\section{The Values of Islamic Quality Management System Based on the Quran and Integration of Scientific Knowledge}

\author{
Hasan Al-Banna Mohamed ${ }^{1}$ \\ Ab Mumin Ab Ghani \\ Siti Arni Basir ${ }^{3}$
}

\begin{abstract}
Al-Quran is a holy kitāb and a complete guidance for mankind to manage all aspects of daily life in this world. The holy Quran and the Sunnah of the Prophet (pbuh) even describe management systems that operate efficiently and effectively. Of course,
\end{abstract}

* Versi asal artikel ini dibentangkan di Seminar Wahyu Asas Tamadun 2 (SWAT 2011), anjuran Fakulti Pengajian Quran dan Sunnah, Universiti Sains Islam Malaysia (USIM), 21-22 September 2011.

1 PhD Candidate, Department of Shariah and Management, Academy of Islamic Studies, University of Malaya, Kuala Lumpur, hasanalbanna@siswa.um.edu.my

2 Associate Professor, Department of Shariah and Management, Academy of Islamic Studies, University of Malaya, Kuala Lumpur, abmumin@um.edu.my

3 Senior Lecturer, Department of Siasah Syar'iyyah, Academy of Islamic Studies, University of Malaya, Kuala Lumpur, sitiarni@um.edu.my 
management system either on the individual, familiy, community, organization or nation that are governed by the guidance of Quran will lead to the ultimate success (al-falāh) of a civilization, not only in this world but in the Akhirat. However, the problems nowadays there are some Muslims who are still awed or applying Western management system which are mostly for temporary or for materialistic benefits only. Therefore, the management systems which are based on the holy Quran should be featured as a guide in addition to integrate with the knowledge of scientific management for implementing or managing an organizations. This article tried to show some aspects of values in managing the administrative affairs of each employees, especially workers in Malaysia. These values include the tawhìdi management concepts, the value of trustworthy leadership and accountability, value of amar ma 'rüf nahi munkar, the implementation of justice ('adālah) and the shürā management principles, together with some suggestions for enhancing the quality management system through an Islamic perspective.

Keywords: Islamic management system, tawhìdì management concepts, accountability, amar ma 'rūf nahī munkar, justice ('adālah), shūrā management

\section{PENDAHULUAN}

Sesungguhnya tiada prasangka lagi bahawa kitab terakhir yang Allah SWT turunkan kepada Nabi Muhammad SAW menjadi sumber utama sebagai rujukan bagi seluruh umat manusia. Al-Quran sememangnya lengkap dan menyeluruh seperti ungkapan dalam Surah al-Baqarah:

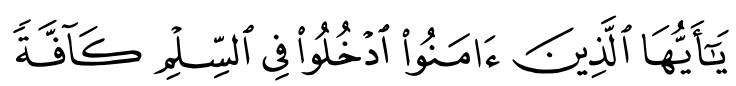

"Wahai orang yang beriman! Masuklah kamu ke dalam agama Islam secara menyeluruh.."

(Surah al-Baqarah, 2: 208)

Ia juga mengandungi segala macam perkara yang tidak ditinggalkan walaupun satu aspek sebagai panduan kehidupan manusia sama ada membabitkan perkara di dunia mahupun di alam akhirat kelak. Firman Allah SWT: 


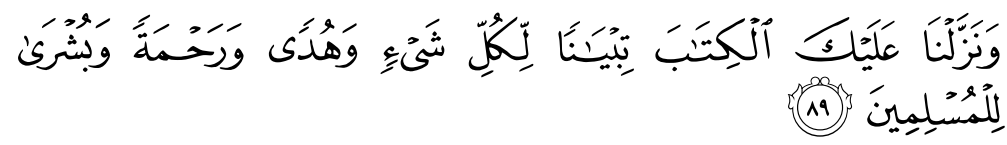

"Dan Kami turunkan kepadamu (wahai Muhammad) kitab (alQuran) untuk menjelaskan tiap-tiap sesuatu dan petunjuk serta rahmat dan khabar gembira bagi orang Muslim.'

(Surah al-Nahl, 16: 89)

Seterusnya, turut dijelaskan dalam Surah al-An'ām:

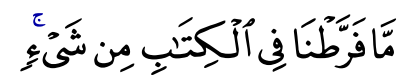

"Tiada Kami tinggalkan sesuatu apa pun di dalam kitab (alQuran) ini.."

(Surah al-An'ām, 6: 38)

Lantaran, ia merupakan suatu mukjizat agung yang sentiasa terpelihara selama-lamanya ${ }^{4}$ khusus bagi seluruh makhluk Allah SWT terutama bagi khalifahNya yang akan mengurus hal-ehwal kehidupan mereka di dunia.

Oleh yang demikian, sistem pengurusan yang berpaksikan ajaran al-Quran dengan penghuraian Sunnah Rasulullah SAW melalui integrasi ilmu-ilmu saintifik moden akan melahirkan suatu sistem urus tadbir yang cemerlang, sempurna dan berkualiti. Rentetan itu, ilmu-ilmu saintifik yang hanya bersesuaian dan tidak menyalahi hukum syara' sahaja yang boleh diambil sandaran bagi mengurus sesebuah organisasi yang cemerlang berpaksikan ajaran Islam. ${ }^{5}$ Rentetan itu, berhubung dengan konsep kecemerlangan pengurusan ini sebenarnya telah pun diungkapkan dalam kitab suci al-Quran dari awal lagi menerusi penciptaan Allah SWT terhadap kejadian-kejadian alam di dunia yang mementingkan aspek kesempurnaan dan berkualiti seperti dalam al-Quran:

\footnotetext{
4 Surah al-Hijr, 15: 9.

5 Ahmad Ibrahim Abu Sin, Pengurusan dalam Islam, cet. ke-2 (Kuala Lumpur: Dewan Bahasa dan Pustaka, 1997), x.
} 


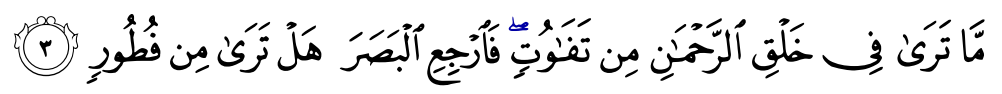

"Kamu tidak dapat melihat pada ciptaan Allah Yang Maha Pemurah itu sebarang keadaan yang tidak seimbang dan tidak munasabah; (Jika kamu ragu-ragu) maka ulangilah pandangan(mu) sekali lagi, Adakah dapat kamu melihat sebarang kecacatan."

(Surah al-Mulk, 67: 3)

Jelas dalam ayat tersebut menunjukkan betapa teliti dan sempurnanya kejadian alam ciptaan Allah SWT tersebut sama ada di langit mahupun di bumi tanpa sebarang kecacatan. Bertitik tolak dari sinilah, Islam menerusi kitab al-Quran dan hadis Rasulullah SAW banyak menyarankan umatnya agar senantiasa melakukan sesuatu pekerjaan dengan sebaik mungkin atau dengan kata lain secara berkualiti dan sempurna. Hal ini kerana sifat kualiti itu adalah sebahagian daripada kehidupan manusia. ${ }^{6}$ Malah ia terjana daripada amalan kecemerlangan yang dihasilkan daripada usaha yang gigih dan berterusan (istiqāmah) dengan penuh semangat iltizam.

\section{SISTEM PENGURUSAN BERKUALITI MENURUT PERSPEKTIF ISLAM}

Sesungguhnya ajaran Islam melalui kitab al-Quran sebenarnya sangat mengutamakan urus tadbir dalam sesebuah organisasi secara berkualiti dan terbaik sama ada dalam aspek pengeluaran produk ataupun memberi perkhidmatan agar dapat menyumbangkan manfaat secara total kepada semua pihak. Malah, Islam sangat menuntut umatnya untuk melaksanakan setiap pekerjaan dengan bersungguh-sungguh melalui niat atau matlamat yang betul bagi mendapatkan keredaan Allah SWT. Justeru, Rasulullah SAW telah menyarankan umatnya agar memulakan sesuatu perkara itu dengan azam dan niat yang betul melalui hadis berikut:

$$
\text { إنما الأعمال بالنيات وانما لكل امرىع ما نوى }
$$

"Sesungguhnya segala amalan itu bermula (bergantung) dengan

\footnotetext{
6 Mohd. Yusof Hj. Othman, Menjejak Kualiti Menjana Kecemerlangan (Kuala Lumpur: Dewan Bahasa dan Pustaka, 2000), 66.
} 
niat, dan hanya bagi setiap manusia itu apa (balasan) yang diniatkannya."

$$
\text { (Riwayat Imām al-Bukhārī dan Muslim RA) }{ }^{7}
$$

Berdasarkan maksud hadis di atas, jelas menggambarkan bahawa setiap individu perlu mempunyai niat yang jelas atau matlamat yang berwawasan dalam hidupnya agar melahirkan keikhlasan atau kejujuran dalam melakukan sesuatu amalan hanya kerana Allah SWT dan rasulNya. Tambahan pula menurut $\mathrm{Covey}^{8}$ dan Morris ${ }^{9}$ bahawa niat terakhir atau wawasan yang betul merupakan prasyarat yang amat penting bagi memastikan kecemerlangan sesuatu tindakan, walaupun memerlukan jangka masa yang panjang.

Bukan itu sahaja, amalan cemerlang atau terbaik tersebut akan memperoleh pahala daripada Allah SWT serta menjadi satu ibadat apabila diurus dengan cara yang betul berlandaskan ajaran al-Quran dan Sunnah Rasulullah SAW. Konsep peribadatan kepada Allah SWT ini telah menjadi matlamat sebenar penciptaan manusia ${ }^{10}$ seperti firman Allah SWT dalam al-Quran:

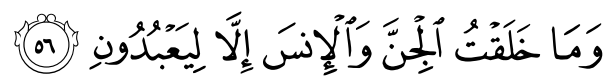

"Dan (ingatlah) Aku tidak mencipta jin dan manusia melainkan untuk mereka menyembah (beribadat) kepada-Ku."

(Surah al-Dhāriyāt, 51: 56)

7 Teks hadith ini sebahagian daripada petikan hadith lengkap dalam Sahih al-Bukhari dan Muslim. Malah hadith ini disebut sebagai (Muttafaq 'Alayh) dan diulang sebanyak tujuh kali Șạị̄ al-Bukhārī kerana maknanya yang sangat penting berkaitan dengan keikhlasan niat seseorang. Rujuk dalam kitab: al-Bukhārī, Abī 'Abd Allāh Muḥammad Ibn Ismā’̄̄l Ibn Ibrāhīm Ibn al-Mughīrah Ibn Bardazibah, Șahịh al-Bukhārī, no. hadith 1, 54, 2529, 3898, 5070, 6689, 6953 (Riyaḍ: Dār alSalām, 1998). Rujuk juga dalam: Muslim, Imam Abū Husayn Muslim Ibn al-Hajjaj Ibn Muslim al-Qushayri al-Naysaburi, Șaḥịh Muslim, no. hadith 1907 (Riyaụ: Dār al-Mughni, 1998).

8 Covey, S. R., The 7 Habits of Highly Effectively People: Powerful Lessons in Personal Change (New York: Simon and Schuster, 2013), 55-56.

9 Morris, T., True Success, A New Philosophy of Excellence (New York: A Grossnet/ Putnam Book, 1994), 59.

10 Ab. Mumin Ab. Ghani, 'Sistem Pengurusan Islam: Tinjauan Menyeluruh dari Aspek Konsep,' dalam Dimensi Pengurusan Islam: Mengurus Kerja dan Mengurus Modal Insan, ed. Ab. Mumin Ab. Ghani dan Fadillah Mansor (Kuala Lumpur: Penerbit Universiti Malaya, 2006), 9. 
Sekiranya dilihat kepada sistem atau ilmu-ilmu saintifik daripada Barat berkenaan dengan pengurusan organisasi, rata-ratanya hanya tertumpu kepada manfaat sementara yang bersifat luaran atau materialistik, ${ }^{11}$ atau semata-mata untuk memuaskan nafsu ekonomi dan kehendak organisasi sahaja. ${ }^{12}$ Malah ia hanya memperoleh kejayaan setakat di dunia sahaja tanpa didasarkan kepada kejayaan yang hakiki (al-falāh) serta keperluan mencari keredaan Ilahi. ${ }^{13}$

Fenomena sebegini adalah sangat berbeza sekali dengan panduan al-Quran yang mementingkan kedua-dua aspek serentak, malah lebih menumpukan kepada pencapaian atau kepuasan pada hari akhirat kelak. Secara umumnya, sistem pengurusan yang dituntut Islam boleh dianggap sebagai satu sistem yang mengurus kehidupan manusia dengan bersumberkan falsafah dan prinsip-prinsip Islam yang lengkap bagi mewujudkan perkhidmatan yang cekap dan sempurna atau produk yang berkualiti. ${ }^{14}$ Justeru, artikel ini akan membincangkan beberapa aspek nilai yang utama dalam menguruskan sesebuah organisasi dalam era globalisasi yang sangat mencabar kini agar ia sentiasa memenuhi keperluan Syariah seperti yang dikehendaki dalam ajaran Islam.

\section{NILAI-NILAI PENGURUSAN ISLAM}

Fokus penulisan dalam artikel ini akan tertumpu pada beberapa nilai penting yang terkandung dalam sistem pengurusan seperti yang disarankan oleh Islam melalui kitab suci al-Quran dan Sunnah Rasulullah SAW untuk dihayati oleh setiap warga kerja dalam organisasi. Sesebuah organisasi ataupun komuniti akan berjaya dalam segala aspek yang diceburi sekiranya setiap ahli saling mengamalkan nilai-nilai murni yang berkualiti dalam diri masing-masing. Hal ini demikian kerana fitrah kesempurnaan atau kecemerlangan yang berkualiti merupakan suatu komponen penting ${ }^{15}$ yang amat diperlukan dalam

11 Fadzila Azni Ahmad, Kaedah Pengurusan Institusi-Institusi Pembangunan Berteraskan Islam di Malaysia (Shah Alam: Pusat Penerbitan Universiti (UPENA), 2010), 55.

12 IIhaamie Abdul Ghani Azmi, 'Pengurusan dari Perspektif Islam,' Jurnal Syariah 9/2 (2001): 85; Lihat juga dalam: Shaharom TM Sulaiman, Pengurusan Islam dan Pembangunan Manusia (Batu Caves: Thinker's Library, 1997), 4-5.

13 Auni Haji Abdullah, Teras Utama Sistem Pengurusan Islam (Kuala Lumpur: Alam Raya Enterprise Sdn. Bhd., 2010), 44.

14 Ilhaamie Abdul Ghani Azmi, 'Pengurusan dari Perspektif Islam,' 90.

15 Nor 'Azzah Kamri, 'Etika Pengurusan Islam dan Konvensional: Satu Analisis Perbandingan,' Jurnal Syariah 10/2 (2002): 54. 
kehidupan seseorang insan. ${ }^{16}$ Antara nilai-nilai pengurusan Islam yang sering ditekankan termasuklah konsep tawhīd $\bar{\imath}$ iaitu kepercayaan atau keimanan yang tulus kepada Allah SWT serta Rasul-Nya, penerapan nilai kepimpinan yang beramanah, sering menerapkan nilai amar ma' 'rūf dan nahī munkār, sentiasa mengamalkan konsep keadilan untuk semua dan yang terakhir adalah membudayakan prinsip pengurusan syura (perundingan secara kolektif) dalam menyelesaikan sebarang permasalahan yang timbul. Kelima-lima nilai penting ini pasti akan membuahkan suatu natijah yang terbaik jika dijadikan sebagai amalan seharian bagi umat Islam yang bekerja tidak kira dalam sebarang organisasi pada setiap masa.

\section{Konsep Pengurusan Tawhīd̄}

Seseorang Muslim tidak akan berjaya sekiranya dalam diri sanubari tiada mempunyai nilai iman yang teguh dan mantap. Nilai atau prinsip iman sangat penting untuk memastikan setiap amalan mendapat keredaan Allah SWT. Oleh sebab itu, tunjang atau paksi kepada kualiti seseorang insan adalah bergantung kepada sifat ketaqwaan dan keimanan sejati yang dihayati dengan erti kata sebenarnya tunduk patuh hanya kepada Pencipta yang Maha Berkuasa iaitu Allah SWT. ${ }^{17}$ Segala tindakan atau pekerjaan individu tersebut akan terus dikaitkan dengan tahap kepercayaan dan keimanan dalam dirinya sama ada benar-benar beriman atau sebaliknya. Oleh sebab itu, falsafah atau konsep menerusi prinsip atau nilai tawhīd $\bar{\imath}$ ini menjadi teras kepada akidah seseorang insan dalam merencana, merancang, menggubal, mengimplementasikan dan menilai sesuatu pengurusan. ${ }^{18}$ Jelas menunjukkan bahawa konsep tawhīdī yang bersifat holistik dan berintegrasi antara materialistik dan spiritual ini amat berbeza sekali dengan falsafah-falsafah yang langsung tidak dikemukakan oleh ilmu saintifik Barat. ${ }^{19}$

16 Mohd. Yusof Hj. Othman, Menjejak Kualiti Menjana Kecemerlangan (Kuala Lumpur: Dewan Bahasa dan Pustaka, 2000), 1.

17 Abdul Ghafar Don, Berhanundin Abdullah dan Zulkiple Abd. Ghani, Dakwah dan Pengurusan Islam di Malaysia: Konsep dan Pelaksanaan (Bangi: Penerbit UKM, 2007), 33

18 Mohd Affandi Hassan, The Tawhidic Approach in Management and Public Administration: Concept, Principles and An Alternative Model (Kuala Lumpur: INTAN, 1992), 55.

19 Nor 'Azzah Kamri, 'Etika Pengurusan Islam dan Konvensional: Satu Analisis Perbandingan,' 54. 
Di samping itu, falsafah tawhìd $\bar{i}$ ini turut juga menekankan bahawa setiap tingkah laku atau tindakan yang lahir sama ada bersifat niat, perkataan atau perlakuan semestinya berpaksikan keimanan kepada Allah SWT yang dikenali sebagai habl min Allah (hubungan seseorang manusia dengan Penciptanya iaitu Allah SWT). Seterusnya diperjelaskan tentang aspek perhubungan manusia sesama manusia ( habl min al-nass) atau dengan makhluk lain serta alam persekitarannya. ${ }^{20}$ Sesungguhnya hubungan manusia sesama manusia akan mementingkan kerjasama dan toleransi antara mereka supaya dapat dipertingkatkan lagi sesuatu produk ataupun perkhidmatan bagi mencapai kesejahteraan hidup seharian. Sekiranya nilai-nilai murni tersebut diabaikan, nescaya kehidupan komuniti organisasi atau masyarakat akan pincang dan mengalami kemusnahan. ${ }^{21}$

Sehubungan dengan itu, Mohd Affandi Hassan menegaskan bahawa paradigma tawhīd $\bar{\imath}$ sebagai,

"satu kaedah ilmu berasaskan kewujudan Tuhan Yang Maha Esa dan Maha Berkuasa serta Maha Adil dan Maha Pengampun serta Maha Sempurna dan tiada satu pun yang menyerupaiNya, Pencipta segala makhluk." 22

Selain itu, sistem pengurusan sesebuah organisasi yang berkualiti semestinya perlu ditambat dengan konsep tawhì $\bar{\imath}$ ini kerana ia merupakan intipati ajaran Islam itu sendiri. Sekiranya seseorang pekerja dalam organisasi mempunyai nilai tawhìd $\bar{\imath}$ yang utuh, nescaya beliau akan melaksanakan tanggungjawab dan amanah yang diberikan dengan sebaik mungkin. Malah komitmen yang tinggi terhadap konsep tawhīd $\bar{\imath}$ tersebut mampu membuahkan hasil dalam usaha memartabatkan keadilan. Semua tenaga kerja dalam organisasi tidak kira dari pihak pengurusan sehinggalah kepada golongan pelaksana akan memastikan keadilan dan kesaksamaan dalam pemberian hak akan diperoleh setiap kakitangan organisasi. Situasi sebegini bukan sahaja melahirkan nilai kepuasan kepada para pekerja atau pelanggan, akan tetapi kesan penyebaran luas nilai keadilan tersebut sekali gus mendatangkan kebahagiaan sejagat dapat dinikmati.

20 Abdul Halim Ismail, 'Penerapan Nilai-Nilai Islam dalam Pentadbiran dan Pengurusan,' Jurnal Dakwah (1987): 140.

21 Ilhaamie Abdul Ghani Azmi, 'Pengurusan dari Perspektif Islam,' Jurnal Syariah 9/2 (2001): 92; Lihat juga dalam: Ahmad Ibrahim Abu Sin, Pengurusan dalam Islam, cet. ke-2 (Kuala Lumpur: Dewan Bahasa dan Pustaka, 1997), 12.

22 Mohd Affandi Hassan, The Tawhidic Approach in Management and Public Administration: Concept, Principles and An Alternative Model, 56-57. 
Justeru, implikasi daripada konsep tawhìd $\bar{\imath}$ ini terhadap seseorang individu sama ada sebagai pekerja bawahan atau pengurus atasan dalam sesebuah organisasi seperti yang ditegaskan oleh IIhaamie Abdul Ghani Azmi ${ }^{23}$ dapat dibahagikan kepada beberapa implikasi, antaranya:

(1) Setiap umat manusia akan bersifat terbuka dan mempunyai matlamat yang jelas serta berpandangan jauh.

(2) Membentuk individu soleh yang bersifat dengan sifat tawā $d u$ ', tidak sombong dan 'ujub, sentiasa bersyukur dengan nikmat yang dikurniakan oleh Allah SWT.

(3) Melahirkan seorang pekerja yang beramanah dan berintegriti tinggi, rajin, cekap dan berdisiplin dalam melaksanakan tugas sebaik mungkin.

(4) Bersikap dengan sifat tawakkal, tidak mudah berputus asa apabila ditimpa sebarang musibah kerana amat percaya dengan qada' dan qadar Allah SWT.

(5) Mempunyai nilai kesabaran serta keazaman yang tinggi dalam diri sendiri.

(6) Bersikap redha, tidak dengki atau iri hati dengan pihak yang lain.

(7) Patuh dan setia kepada peraturan atau undang-undang yang telah ditetapkan dalam al-Quran dan Sunnah Rasulullah SAW.

\section{Nilai Kepimpinan yang Beramanah dan Akauntabiliti}

Nilai seterusnya dalam sistem pengurusan Islam berkualiti adalah nilai yang perlu ada dalam setiap kepimpinan organisasi. Jika pemimpin dalam sesebuah organisasi tidak mempunyai nilai-nilai murni sudah pasti kelangsungan organisasi tersebut akan terencat dan terbantut. Malah, konsep kepimpinan dalam Islam sememangnya menjadi isu atau topik terpenting dalam memastikan pengurusan sesuatu perkara sama ada dalam aspek sosial, ekonomi, politik ataupun pentadbiran dapat berjalan dengan lancar dan sempurna. Penekanan terhadap nilai kepimpinan yang membawa kepada pengurusan berkualiti sudah semestinya banyak dibicarakan oleh sarjana Barat dan Timur seperti Deming, Juran, Crosby dan Masaaki Imai ${ }^{24}$ serta cendekiawan Muslim terutamanya apabila hendak melantik seseorang menjadi pemimpin organisasi. Dalam

23 Ilhaamie Abdul Ghani Azmi, 'Pengurusan dari Perspektif Islam,' 92.

24 Mumtaz Begam Abdul Kadir dan Mohammed Sani Ibrahim, Integriti Peningkatan Kualiti Organisasi (Kuala Lumpur: Utusan Publications \& Distributors Sdn. Bhd., 2009), 36. 
hal ini Rasulullah SAW telah pun menegaskan bahawa setiap individu itu merupakan seorang pemimpin kepada orang lain melalui sabdanya:

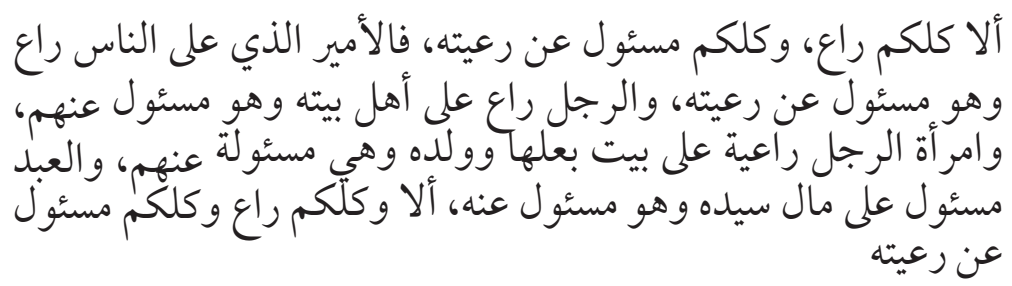

"Kamu semua adalah pemimpin dan kamu semua akan bertanggungjawab terhadap apa yang kamu pimpin. Seorang pemerintah adalah pemimpin dan dia akan bertanggungjawab terhadap rakyatnya. Seorang suami adalah pemimpin bagi ahli keluarganya dan dia akan bertanggungjawab terhadap mereka. Manakala seorang isteri adalah pemimpin rumah tangga, suami dan anak-anaknya, dia akan bertanggungjawab terhadap mereka. Seorang hamba adalah penjaga harta tuannya dan dia juga akan bertanggungjawab terhadap jagaannya. Ingatlah, kamu semua adalah pemimpin dan akan bertanggungjawab terhadap segala yang kamu pimpin."

$$
\text { (Riwayat Imam al-Bukhārī RA) }{ }^{25}
$$

Sesungguhnya kepimpinan bukanlah suatu yang teristimewa, akan tetapi merupakan satu amanah yang amat berat ${ }^{26}$ yang dapat didefinisikan sebagai suatu proses yang melibatkan seorang pengurus yang berusaha sedaya mungkin untuk mendapatkan penyertaan secara sukarela daripada orang bawahannya agar objektif yang ditetapkan dapat dicapai sepenuhnya. ${ }^{27}$ Malah, kepimpinan memerlukan ilmu pengetahuan, sifat keadilan ('adālah), kecekapan, keberanian (syajā'ah), ketabahan, kejujuran, kecekalan, akhlak mulia, kesabaran, sifat pemaaf, kesihatan dan kesempurnaan tubuh badan serta mental, dan akhirnya

25 Al-Bukhārī, Șaḥīh al-Bukhārī, Kitab al-Aḥkām, no. hadith 7138 (Beirūt: Dār Ibn Kathīr, 1998), 1764.

26 Panel Pengurusan YaPIEM, Pengurusan Islami: Menghayati Prinsip dan Nilai Qurani (Kuala Lumpur: Akademi Pengurusan YaPIEM, 2010), 111.

27 Siti Arni Basir, 'Pengurusan Organisasi dari Perspektif Islam: Satu Kajian Kes di Perbadanan Johor dan SAPURA Holdings,' Jurnal Syariah 1/9 (2001): 67. 
kebijaksanaan (fațanah). Kesemua ini dianggap sebagai antara syarat utama untuk menjadi seorang pemimpin atau ketua. ${ }^{28}$

Menurut Mumtaz Begam Abdul Kadir dan Mohammed Sani Ibrahim ${ }^{29}$ bahawa pemimpin dalam Islam mesti memenuhi dua kriteria yang penting iaitu: Pertama ialah individu yang memerintah dengan hak yang dianugerahkan Allah SWT (patuh kepada perintah Allah SWT dan rasul-Nya), kedua pula ialah seorang yang dihormati seperti termaktub dalam al-Quran:

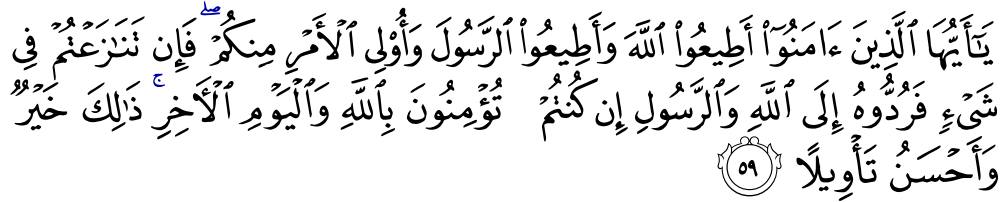

"Wahai orang-orang yang beriman, taatlah kamu kepada Allah dan taatlah kamu kepada Rasulullah dan kepada Ulil-Amri (orang-orangyang berkuasa) dari kalangan kamu. Kemudian jika kamu berbantah-bantah (berselisihan) dalam sesuatu perkara, maka hendaklah kamu mengembalikannya kepada (Kitab) Allah (al-Quran) dan (Sunnah) Rasul-Nya, jika kamu benar beriman kepada Allah dan hari akhirat. Yang demikian adalah lebih baik (bagi kamu), dan lebih elok pula kesudahannya."

(Surah al-Nisā', 4: 59)

Bukan itu sahaja, seseorang pemimpin perlu menjalinkan perhubungan dua hala yang erat antara pihak-pihak tertentu disebabkan mereka saling memerlukan antara satu sama lain. Tambahan pula, pemimpin tersebut mampu mewujudkan suasana bekerja yang kondusif serta berupaya membentuk persefahaman antara warga organisasi, akan melahirkan suasana bekerja

28 Mohd Affandi Hassan, The Tawhidic Approach in Management and Public Administration: Concept, Principles and An Alternative Model, 243-244. Sila rujuk juga kepada sepuluh ciri-ciri asas kepimpinan yang dikemukakan oleh Abu al-'Ainain, J. J., The Principles of Management in Quran and Sunnah (Beirut: Al-Hilal Publishing Company, 2002), 75-79. Dalam Muhammad A. Al-Buraey, Islamic Principles in The Management of An Organization: A Focus on Leading (Kuala Lumpur: IKIM, 2005), 63-87. Ciri-ciri tersebut adalah: (1) Strength of Character (2) Role Model (3) Equity \& Impartiality (4) Kindness \& Magnanimity (5) Integrity (6) Guidance (7) Consultation (8) Unselfishness (9) Competence; dan (10) Intelligence \& Wisdom.

29 Mumtaz Begam Abdul Kadir dan Mohammed Sani Ibrahim, Integriti Peningkatan Kualiti Organisasi, 49. 
secara bermuafakat dan kolektif (jamā'ah). ${ }^{30}$ Jika sebaliknya pemimpin dalam sesebuah organisasi bersikap autokratik, tidak mendengar rungutan pihak pelanggan, tidak mementingkan keperluan orang bawahan atau pekerjanya, tidak bersikap amanah (khiyānah) serta sering bersikap zalim, nescaya organisasi tersebut akan mengalami permasalahan.

Justeru, nilai utama yang perlu wujud dalam diri seseorang pemimpin adalah sifat amanah dan akauntabiliti yang tinggi. ${ }^{31}$ Sesungguhnya pemimpin hendaklah amanah dalam menjalankan tugasnya sama ada dari aspek perkataan iaitu jujur dengan mengotakan setiap yang dijanjikan dan juga melalui perbuatannya dengan menunaikan sekadar termampu kepada orang bawahannya yang memerlukan bantuan dan pertolongan. Manakala konsep akauntabiliti seperti yang dijelaskan oleh Siti Arni Basir ${ }^{32}$ bermaksud seseorang individu yang memikul tugasan hendaklah melaksanakannya dengan sebaik mungkin dan perlu menjawab terhadap sebarang permasalahan yang timbul kesan daripada pelaksanaan tugas tersebut. Menurut Islam, konsep akauntabiliti merupakan suatu amanah yang wajib dipikul oleh setiap individu dan akan dipersoalkan di hadapan Allah SWT segala tindakannya pada hari akhirat kelak. Oleh itu, kebertanggungjawaban atau konsep akauntabiliti ini adalah selari dengan firman Allah SWT dalam al-Quran iaitu:

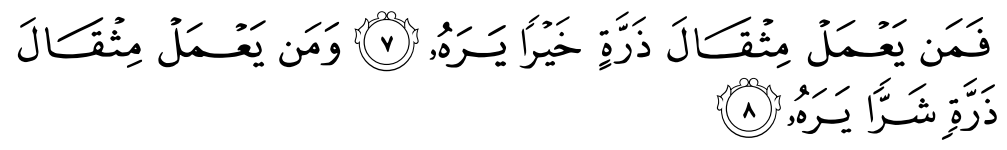

"Maka sesiapa berbuat kebajikan seberat zarah (atom), nescaya akan diperlihatkannya (dalam surat amalannya). Dan sesiapa yang berbuat kejahatan seberat zarah (atom) pun, nescaya akan diperlihatkannya (dalam surat amalnya)."

(Surah al-Zalzalah, 99: 7-8)

Di samping itu, setiap pemimpin juga haruslah menerapkan nilai-nilai murni yang lain dalam diri sendiri serta mempamerkan ciri-ciri kepimpinan yang berkualiti melalui contoh terbaik kepada pihak lain. Hal ini demikian

30 Sharifah Hayati Syed Ismail al-Qudsy, 'Muafakat Tingkat Kualiti Kerja,' Berita Harian, 2 Julai 2011.

31 Nik Mustapha Nik Hassan, 'The Way Forward: Enchancing Islamic Leadership in The Globalized World,' Kertas kerja seminar International Conference on Islamic Leadership (ICIL 2011) (Kuala Lumpur, Hotel Royale Chulan, 4-5 Oktober 2011).

32 Siti Arni Basir, 'Pengurusan Organisasi dari Perspektif Islam: Satu Kajian Kes di Perbadanan Johor dan SAPURA Holdings,' 70. 
kerana pemimpin yang mempunyai etika atau nilai sebegini akan mudah memperoleh kepercayaan dan kesetiaan daripada pengikut serta dihormati oleh para pekerjanya. ${ }^{33}$

Hasil penghuraian di atas jelas menunjukkan bahawa konsep kepimpinan yang ditekankan oleh ilmu saintifik moden daripada Barat hanya menumpukan kepada aspek pencapaian objektif dalam sesebuah organisasi sahaja ataupun hanya sekadar keupayaan mempengaruhi seseorang untuk melakukan sesuatu pekerjaan. Sedangkan ajaran al-Quran serta Sunnah Rasulullah SAW dalam membincangkan konsep kepimpinan adalah jauh lebih menjangkau daripada peranan tersebut, ia melihat dari perspektif yang lebih luas dengan menyatakan bahawa manusia sebagai khalifah Allah yang mempunyai tiga tugas yang besar ${ }^{34}$ iaitu manusia sebagai pengurus, pentadbir dan pemimpin. Pertamanya sebagai pengurus, seseorang perlu sedaya upaya memastikan matlamat terakhir manusia iaitu mencapai kejayaan hakiki (al-falāh) tercapai. Manakala peranan sebagai pentadbir pula, perlu memastikan semua rakyat atau pengikut bawahannya diurus secara adil dan saksama tanpa penindasan serta tiada pembaziran berlaku. Peranan terakhir adalah sebagai pemimpin yang semestinya harus membawa pengikutnya ke arah kejayaan hakiki (alfalāh) serta menjauhi segala perkara yang mungkar. Dan ketiga-tiga peranan tersebut tidak mampu dilaksanakan kecuali dengan ilmu pengetahuan yang mapan yang dapat membezakan antara yang hak dan batil. ${ }^{35}$

\section{Nilai Amar Ma'rūf Nahī Munkar}

Nilai ketiga yang dikemukakan dalam artikel ini ialah nilai amar ma 'rū $f$ dan nah̄ munkar. Kedua-dua istilah ini sering dikaitkan secara bersama apabila diperbincangkan tentang tugas dakwah bagi seseorang khalifah Allah SWT. Tugas atau misi menyampaikan perintah Allah SWT yang baik (ma'rüf) dan mencegah setiap yang dilarangNya (munkar) merupakan suatu tanggungjawab primer terutamanya dalam tradisi Nubuwwah. Istilah amar ma'rüf dapat

33 Siti Arni Basir, 'Pengurusan Organisasi dari Perspektif Islam: Satu Kajian Kes di Perbadanan Johor dan SAPURA Holdings,' 67.

34 Mohd Affandi Hassan, The Tawhidic Approach in Management and Public Administration: Concept, Principles and An Alternative Model, 243.

35 Sila rujuk kepada kertas pembentangan Profesor daripada Jabatan Sains Politik, Universiti Kebangsaan Singapura iaitu Hussin Mutalib, 'Islamic Leadership for Peaceful and Prosperous ASEAN,' Kertas seminar International Conference on Islamic Leadership (ICIL 2011) (Kuala Lumpur, Hotel Royale Chulan, 4-5 Oktober 2011). 
didefinisikan sebagai suatu ajakan atau perintah ke arah melaksanakan amalan yang baik secara bimbingan dan nasihat yang bijaksana, bertukartukar pandangan, banyak bersabar, berlemah lembut, sering menunaikan solat dan berdoa, berlapang dada, ikhlas dan bertoleransi. Hal ini demikian kerana suruhan melakukan amalan yang baik merupakan satu amanah yang telah diwartakan oleh Allah SWT terhadap junjungan para nabi dan rasulNya agar membentuk masyarakat dan ummah yang terbaik.

Manakala istilah nahī munkar pula ditakrifkan sebagai menyatakan sesuatu larangan terhadap masyarakat umum agar menjauhi segala kemaksiatan atau perkara-perkara yang negatif yang boleh mengakibatkan kehidupan umat tidak tenteram dan aman. Justeru Allah SWT telah berfirman dengan memerintah agar umat manusia sentiasa menyeru ke arah kebaikan dan mencegah segala larangan sama ada dalam al-Quran atau Sunnah Rasulullah SAW seperti:

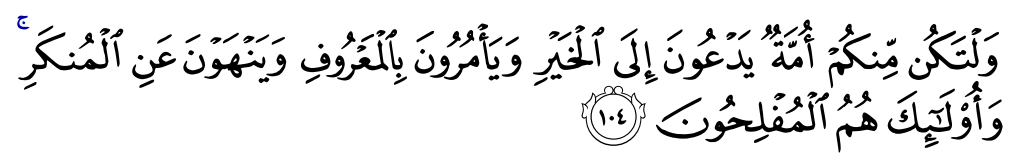

"Dan hendaklah ada antara kamu satu puak yang menyeru (berdakwah) kepada kebajikan (mengembangkan Islam), dan menyuruh berbuat segala perkara yang baik, serta melarang daripada segala yang salah (buruk dan keji). Dan mereka yang bersifat demikian ialah orang-orang yang berjaya."

(Surah Āli-'Imrān, 3: 104)

Firman Allah SWT lagi :

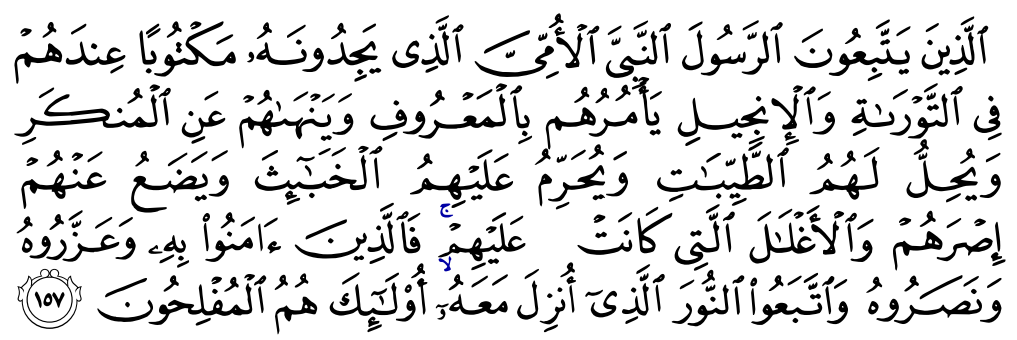

"Iaitu orang-orang yang mengikut Rasulullah (Muhammad SAW) Nabi yang Ummi, yang mereka dapati tertulis (namanya dan sifat-sifatnya) di dalam Tawrat dan Injil yang ada di sisi mereka. Ia menyuruh mereka dengan perkara-perkara yang baik, dan melarang mereka daripada melakukan perkara-perkara yang keji; dan ia menghalalkan bagi mereka segala benda yang baik, dan mengharamkan kepada mereka segala benda yang buruk; dan 
ia juga menghapuskan dari mereka beban-beban dan belenggubelenggu yang ada pada pada mereka. Maka orang-orang yang beriman kepadanya, dan memuliakannya, juga menolongnya, serta mengikut Nur (cahaya) yang diturunkan kepadanya (alQuran), mereka itulah orang-orang yang berjaya."

(Surah al-A'rāf, 7: 157)

Menerusi kefahaman ayat-ayat di atas, ia menggambarkan bahawa setiap pemimpin atau pengikut perlu memastikan nilai amar ma ' $r u \bar{f}$ dan nahī munkar ini sentiasa dibudayakan agar sistem pengurusan dalam kehidupan seharian dapat berjalan lancar dan berkesan. Melalui pelaksanaan kedua-dua nilai ini juga, umat manusia terutamanya golongan Muslim diangkat martabatnya ke peringkat yang tinggi dan dihormati oleh bangsa-bangsa yang lain seperti firman Allah SWT dalam al-Quran:

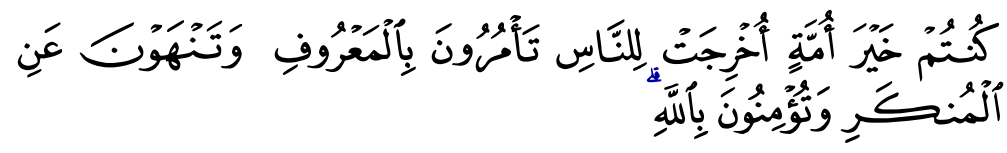

"Kamu (wahai umat Muhammad) adalah sebaik-baik umat yang dilahirkan bagi (faedah) umat manusia, (kerana) kamu menyuruh berbuat segala perkara yang baik dan melarang daripada segala perkara yang salah (buruk dan keji), serta kamu pula beriman kepada Allah (dengan sebenar-benar iman)."

(Surah Āli-'Imrān, 3: 110)

Firman Allah SWT lagi:

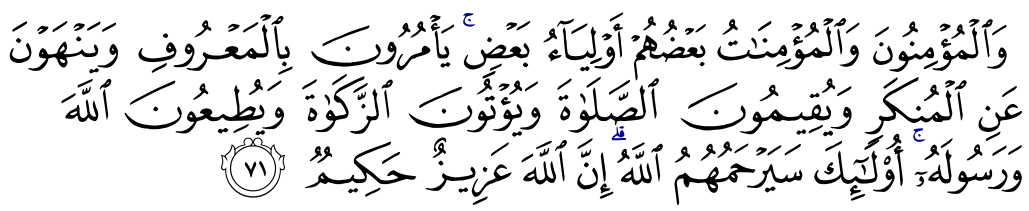

"Dan orang-orang yang beriman, lelaki dan perempuan, setengahnya menjadi penolong bagi setengahnya yang lain; mereka menyuruh berbuat kebaikan, dan melarang daripada berbuat kejahatan; dan mereka mendirikan sembahyang dan memberi zakat, serta taat kepada Allah dan Rasul-Nya. Mereka itu akan diberi rahmat oleh Allah. Sesungguhnya Allah Maha Berkuasa, lagi Maha Bijaksana.'

(Surah al-Tawbah, 9: 71) 
Perintah amar ma'rū f dan nahī munkar ini bukan sekadar diperintahkan oleh Allah SWT, malah nabi Muhammad SAW turut menggesa umatnya melaksanakan nilai-nilai tersebut melalui hadis berikut:

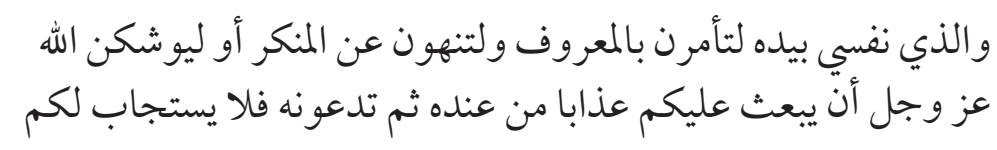

"Hendaklah kamu melaksanakan amar ma'rūf nahī munkar atau Allah akan bertindak tegas akibat dari dosa-dosa kamu, apabila kamu berdoa nescaya Dia (Allah) tidak akan menerimanya."

(Riwayat oleh Imam al-Tirmidhī RA) ${ }^{36}$

Oleh itu, setiap umat perlu menanam sifat dan sikap seperti yang ditunjukkan oleh junjungan besar nabi Muhammad SAW sebagai pendakwah ( $d \bar{a}$ ‘ $i e)$ dan pemimpin (khalifah) yang berkaliber dengan sanggup berkorban harta, jiwa dan tenaga demi menegakkan kebenaran dan membasmi kepalsuan. Menurut Ibn Taymiyyah, individu yang ingin melaksanakan nilai amar ma ' $r \bar{u} f$ dan $n a h \bar{\imath}$ munkar tersebut perlulah mempunyai kefahaman yang mapan serta kesabaran yang tinggi, bersopan-santun dan lemah lembut dengan berprinsipkan keimanan dan keyakinan yang sebenar kepada Allah SWT dan Rasul-Nya. ${ }^{37}$ Berikut adalah antara sifat yang boleh diteladani dalam urusan amar ma 'rūf nahī munkar seperti firman Allah SWT dalam al-Quran:

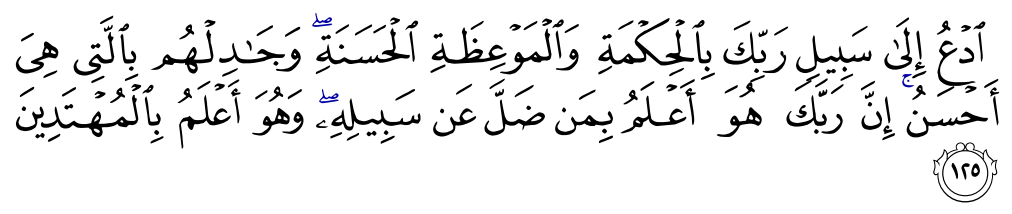

"Serulah ke jalan Tuhan mu (wahai Muhammad) dengan hikmat kebijaksanaan dan nasihat pengajaran yang baik, dan berbahaslah dengan mereka (yang engkau serukan itu) dengan cara yang lebih baik; sesungguhnya Tuhanmu Dia lah jua yang lebih mengetahui akan orang yang sesat dari jalan-Nya, dan Dia lah jua yang lebih mengetahui akan orang-orang yang mendapat hidayah petunjuk."

(Surah al-Naḥl, 16: 125)

\footnotetext{
36 Al-Tirmidhī, Abū 'Īsā Muhammad Ibn 'Īsā Ibn Surah, Sunan al-Tirmidhī, Taḥqīq: Dr. Bashar Awwad Maarof, vol. 4, no. hadīth 2169 (Beirūt, Dār al-Gharb al-Islāmī, t.t.), 42.

37 Abu Fahmi, Etika Beramar Makruf Nahi Mungkar (Jakarta: Gema Insani Press, 2001), 12.
} 
Secara umumnya, jelas bahawa nilai amar ma 'rüf dan nahī munkar ini perlu dijadikan satu prinsip penting dalam sistem pengurusan sesebuah organisasi dalam masyarakat agar dapat membentuk kerangka sistem kehidupan yang berkualiti dan terbaik mengikut perspektif dan panduan Islam sepenuhnya.

\section{Pelaksanaan Keadilan ('Adālah)}

Menurut Ibn Taymiyyah melalui bukunya al-Siyāsah al-Syar 'iyyah fì Ișlāh al$R a$ ' $\imath$ wa al-Ra 'iyyah, telah mengemukakan bahawa prinsip pengurusan Islam seharusnya berlandaskan kepada firman Allah SWT dalam al-Quran iaitu :

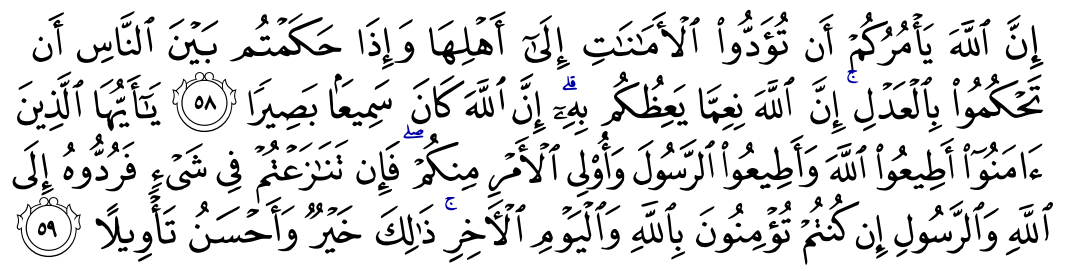

"Sesungguhnya Allah menyuruh kamu supaya menyerahkan segala jenis amanah kepada ahlinya (yang berhak menerimanya), dan apabila kamu menjalankan hukum di antara manusia, (Allah menyuruh) kamu menghukum dengan adil. Sesungguhnya Allah dengan (suruhan-Nya) itu memberi pengajaran yang sebaikbaiknya kepada kamu. Sesungguhnya Allah sentiasa Mendengar, lagi sentiasa Melihat. Wahai orang-orang yang beriman, taatlah kamu kepada Allah dan taatlah kamu kepada Rasulullah dan kepada 'Uli al-Amri'(orang-orang yang berkuasa) dari kalangan kamu. Kemudian jika kamu berbantah-bantah (berselisihan) dalam sesuatuperkara, maka hendaklah kamu mengembalikannya kepada (Kitab) Allah (al-Quran) dan (Sunnah) Rasul-Nya jika kamu benar beriman kepada Allah dan hari akhirat. Yang demikian adalah lebih baik (bagi kamu), dan lebih elok pula kesudahannya."

(Surah al-Nisā', 4: 58-59)

Melalui kefahaman kedua-dua ayat di atas menggambarkan bahawa ayat yang pertama ditujukan kepada setiap pemimpin atau pemerintah adalah wajib menunaikan amanah yang dipertanggungjawab terhadap mereka dengan sebaik mungkin. Sekiranya ingin melaksanakan sesuatu hukuman atau tindakan, maka perlulah menjatuhkan hukuman secara adil dan saksama. Manakala ayat kedua pula lebih ditujukan kepada pihak bawahan yang dipimpin atau dengan 
kata lain pengikut dan rakyat. Antara lain hendaklah sentiasa mentaati perintah ketua atau pemimpin selagi mereka tidak melanggar perintah Allah SWT dan rasulNya. Selain itu, sekiranya terjadi perselisihan faham atau pendapat, hendaklah terus merujuk kepada kitab al-Quran dan Sunnah Rasulullah SAW.

Situasi inilah menjadi prinsip atau dasar yang utama dalam memastikan sesuatu sistem pengurusan dalam organisasi mampu dilaksanakan dengan sebaik mungkin secara berkualiti dan berkesan. Malah seluruh umat Islam telah disarankan agar sentiasa berlaku adil terhadap pihak lain dalam setiap urusan mereka dan ditegah melakukan sebarang tindakan diskriminasi atau pilih kasih yang didasari ikatan kekeluargaan ataupun minat peribadi seseorang. ${ }^{38}$ Bukan itu sahaja, pengurus seharusnya memberikan ganjaran kepada para pekerjanya secara adil dan saksama, ${ }^{39}$ mengikut kelayakan dan tugas yang diamanahkan ${ }^{40}$ serta mengelak daripada bersikap prejudis kepada orang lain walaupun berbeza jantina, kaum, bangsa atau warna kulit.

Di samping itu, pengurus mestilah mempunyai sikap sebagai pemudahcara dalam menangani urusan yang berkaitan dengan organisasi dan keperluan pekerja. Hal ini selari dengan kehendak Islam yang menyeru kepada umatnya untuk memudahkan urusan orang lain seperti yang terkandung dalam hadis Rasulullah SAW iaitu :

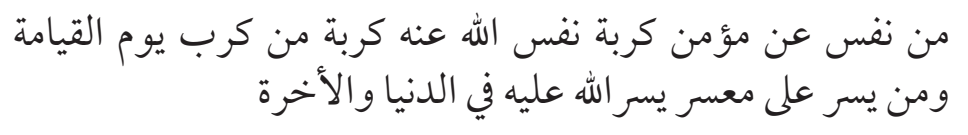

"Sesiapa yang melapangkan dari orang Mukmin kesusahan dunia, nescaya Allah akan melapangkan dia dari satu kesusahan dari segala kesusahan pada hari qiamat. Dan sesiapa yang memudahkan atas orang yang susah, nescaya Allah akan memudahkan atasnya di dunia dan akhirat."

(Riwayat oleh Imām Muslim RA) ${ }^{41}$

38 Muhammad 'Abd al-Rauf, Management and Adminstration from an Islamic Perspective, $1^{\text {st }}$ ed. (Kuala Lumpur: Islamic Affairs Division, Prime Ministers Department, 1987), 6-8.

39 Surah al-Baqarah, 2: 286.

40 Abdul Ghafar Don, Berhanundin Abdullah dan Zulkiple Abd. Ghani, Dakwah dan Pengurusan Islam di Malaysia: Konsep dan Pelaksanaan, 35.

41 Muslim, Imām Abū Husayn Muslim Ibn al-Hajjāj Ibn Muslim al-Qushayrī alNaysābūrī, Șaḥ̄ḥ Muslim, no. hadīth 2699 (Riyāộ: Dār al-Mughnī, 1998). 
Begitu juga dengan pengagihan dan pengurusan perbelanjaan sumbersumber bagi sesebuah organisasi yang seharusnya diurus tadbir secara telus, berhati-hati dan tiada berlaku pembaziran atau penyalahgunaan kuasa. ${ }^{42} \mathrm{Hal}$ ini demikian kerana sekiranya seseorang pemimpin organisasi bersikap zalim dan tidak adil, pasti akan melahirkan ketidakpuasan hati para pengikut, penindasan dan ketidakseimbangan serta tidak dihormati oleh pihak yang lain. Justeru, sikap wasațiyyah atau kesederhanaan amatlah dituntut dalam Islam yang sememangnya selari dengan fitrah atau status manusia sebagai khalifah di muka bumi ini seperti firman Allah SWT dalam al-Quran:

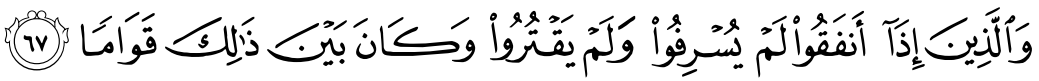

"Dan juga mereka (yang diredhai Allah itu ialah) yang apabila membelanjakan hartanya, tiadalah melampaui batas dan tiada bakhil kedekut; dan (sebaliknya) perbelanjaan mereka adalah betul sederhana di antara kedua-dua cara (boros dan bakhil) itu."

(Surah al-Furqān, 25: 67)

\section{Prinsip Pengurusan Syura}

Nilai terakhir terhadap sistem pengurusan kualiti Islam adalah membabitkan prinsip pengurusan syura seperti yang disarankan melalui kitab suci al-Quran dan Sunnah Rasulullah SAW, kalimah syura ini lahir daripada perkataan alIstisyārah yang bermaksud satu perundingan atau bermesyuarat (berbincang) atau kerja berpasukan untuk mencari penyelesaian terhadap satu-satu masalah dan memutuskannya apabila telah mengetahui jalan atau cara penyelesaiannya. ${ }^{43}$ Istilah syura telah didefinisikan ramai cendekiawan Islam antaranya Ibn 'Arabī yang menjelaskan bahawa syura sebagai satu permesyuaratan untuk mencari pendapat atau nasihat dalam mencari sesuatu kepastian. ${ }^{44}$ Menurut Ibn 'Atiyyah pula menerangkan konsep syura diasaskan dengan tujuan mewujudkan perbincangan dua hala antara cerdik pandai dan ahli agama dalam menyelesaikan sesuatu permasalahan. ${ }^{45}$ Manakala menurut Muhammad

42 Abdul Ghafar Don, Berhanundin Abdullah dan Zulkiple Abd. Ghani, Dakwah dan Pengurusan Islam di Malaysia: Konsep dan Pelaksanaan, 38.

43 Abdullah Alwi Hj. Hassan, 'Al-Shura: Konsep dan Penerapannya dalam Organisasi dan Pentadbiran,' Monograf Islamika III, cet. 1 (Kuala Lumpur: Persatuan Muzium Malaysia, 1985), 71.

44 Ilhaamie Abdul Ghani Azmi, 'Pengurusan dari Perspektif Islam,' 93.

45 Abdullah Alwi Hj. Hassan, 'Al-Shura: Konsep dan Penerapannya dalam Organisasi dan Pentadbiran,' 71. 
A. al-Buraey, syura boleh ditakrifkan sebagai satu proses pengurusan atau alat untuk mencapai sesuatu keputusan secara kolektif. ${ }^{46}$

Merujuk kepada sīrah nabawiyyah, sememangnya konsep syura ini telah pun diamalkan sejak lama dulu terutamanya oleh Baginda Rasulullah SAW dan kemudiannya disusuli oleh para Khulafā' al-Rāsyidīn dan sahabat-sahabatnya. Ia turut ditegaskan dalam ayat-ayat al-Quran dan hadis nabi sebagai satu nas atau dalīl naqlī bahawasanya konsep syura ini dianggap sebagai satu lambang asasi bagi perundangan (al-Syarī'ah) dan sebagai penetapan bagi sesuatu hukum. ${ }^{47}$ Sesungguhnya Allah SWT telah berfirman dalam al-Quran:

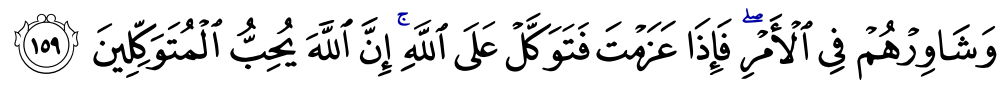

"Dan juga bermesyuaratlah dengan mereka dalam urusan (peperangan dan hal-hal keduniaan) itu. Kemudian apabila engkau telah berazam (sesudah bermesyuarat, untuk membuat sesuatu) maka bertawakallah kepada Allah, sesungguhnya Allah mengasihi orang-orang yang bertawakal kepadaNya."

(Surah Āli-'Imrān, 3: 159)

Firman Allah SWT lagi iaitu:

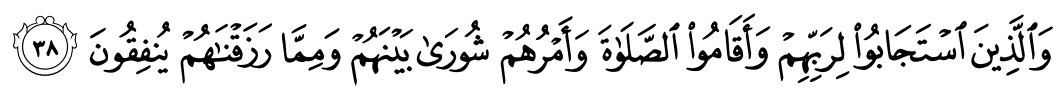

"Dan juga (lebih baik dan lebih kekal bagi) orang yang menyahut dan menyambut perintah Tuhannya serta mendirikan sembahyang dengan sempurna; sedangkan urusan mereka dijalankan secara bermesyuarat sesama mereka; dan mereka pula mendermakan sebahagian dari rezeki yang Kami berikan kepada mereka."

(Surah al-Syūrā, 42: 38)

\footnotetext{
46 Muhammad A. Al-Buraey, Administrative Development: An Islamic Perspective (London: K.P.I., 1985). Lihat juga: Muhammad A. Al-Buraey, 'Management Principles Derived from Sources of Islam,' dalam Quality Standard from the Islamic Perspective, ed. Mazilan Musa dan Shaikh Mohd Saifuddeen Shaikh Mohd Salleh (Kuala Lumpur: IKIM, 1985), 37-40.

47 Abdullah Alwi Hj. Hassan, 'Al-Shura: Konsep dan Penerapannya dalam Organisasi dan Pentadbiran,' 71.
} 
Di samping itu, terdapat Āthār dari Tabi'in iaitu kata-kata Hasan al-Bașrī yang diriwayatkan dalam Musannaf Ibn Abī Shaybah ${ }^{48}$ dan dalam kitab alAdab al-Mufrad daripada Imam al-Bukhārī RA yang turut menggalakkan amalan syura atau bermesyuarat ini dengan lafaz:

$$
\text { ما تشاور قوم قط إلا هدوا لأرشد أمورهم }
$$

"Tiada bermesyuarat sesuatu kaum melainkan kerana mereka ingin mengarahkan kepada penyampaian jalan yang sewaras mungkin dalam urusan mereka." 49

Di samping itu, terdapat juga $\bar{A} t h \bar{a} r$ daripada ḥukamā' yang dinyatakan dalam kitab al-Mu'jam al-Ṣaghīr oleh al-Ṭabarānī turut menegaskan perkara ini dengan lafaznya:

$$
\text { ما خاب من استخار ولا ندم من استشار، و لا عال من اقتصد }
$$

"Tiada sia-sia mereka yang memohon istikharah (Allah dalam urusan mereka), tiada penyesalan mereka yang bermesyuarat dalam urusan mereka, dan tiada tewas mereka yang tahu berjimat cermat." 50

Kepentingan syura dapat dilihat tatkala Islam merupakan agama yang menyeru kepada budaya tegur-menegur atau nasihat-menasihati seperti yang ditegaskan dalam hadis Rasulullah SAW iaitu:

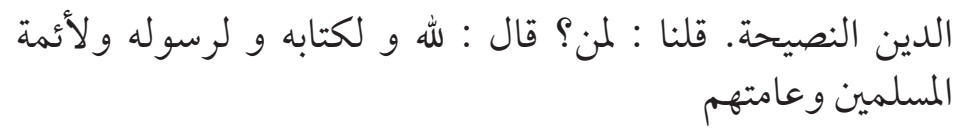

"Agama itu nasihat. Kami berkata: Untuk siapa? Baginda bersabda: Bagi Allah dan bagi kitabnya dan bagi Rasul-Nya serta imam-imam kaum muslimin dan bagi orang ramai keseluruhan mereka."

\section{(Riwayat oleh Imām Muslim RA) ${ }^{51}$}

48 Al-Kufī, Muhammad Ibn Abī Shaybah, Musannaf Ibn Abī Shaybah, vol. 5, no. hadīth 26275 (Riyāẹ: Maktabah al-Rusd, 1409H), 298.

49 Al-Bukhārī, Abī 'Abd Allāh Muhammad Ibn Ismā'īl Ibn Ibrāhīm Ibn al-Mughīrah Ibn Bardazibah, al-Adab al-Mufrad, vol. 1, no. hadīth 258 (Beirūt: Dār al-Basyā' ir al-Islāmiyyah, 1989), 100.

50 Al-Ṭabaran̄̄, Abū al-Qāsim Sulayman Ibn Aḥmad, al-Mu'jam al-Saghīr, vol. 2, no. hadīth 980 (Beirūt: al-Maktab al-Islāmīi, 1985), 175.

51 Syaikh Muḥammad Ibn Șālị̣ al-'Utsaymin, Syarḥ al-Arba’in al-Nawawiyyah, terj. Abu Ahsan Sirojuddin Hasan Bashri (Jakarta: Pustaka Ibnu Kathir, 2009), 182. 
Konsep syura turut diamalkan oleh khalifah-khalifah selepas kewafatan Rasulullah SAW antaranya khalifah 'Umar al-Khatțāb RA yang pernah mengisytiharkan bahawa:

$$
\text { وقد جعل عمر بن الخطاب الخلافة، وهي أعظم النوازل-شورى }
$$

"Sesungguhnya 'Umar Ibn al-Khațāà telah meletakkan/ membentuk Khalifah (sistem kepimpinan) yang merupakan urusan terbesar - berdasarkan syura." 52

Seterusnya, konsep syura ini cuba dihidupkan kembali pada zaman pemerintahan 'Umar Ibn 'Abd al-'Azīz semasa dinasti 'Umayyah dan Khalifah al-Makmun pada zaman dinasti 'Abbasiyyah. ${ }^{53}$

Jika diteliti berkenaan ilmu saintifik Barat tentang sistem pengurusan sesebuah organisasi sudah semestinya ia bersifat terhad, tidak menyeluruh dan hanya menekankan kejayaan yang sementara. Oleh sebab itu, konsep bermesyuarat ataupun syura perlu dijadikan alternatif yang terbaik dalam sistem organisasi kerana ia merupakan satu konsep yang dinamik yang merangkumi aspek kepimpinan dan aspek pengurusan itu sendiri. Bahkan melalui mesyuarat, ahli-ahli dapat bertukar pandangan dan idea sesama sendiri, bukan hanya mengikut hawa nafsu sahaja serta dapat mengukuhkan lagi keharmonian dan perhubungan șilah al-rahìm antara mereka. ${ }^{54}$ Tambahan pula pemimpin yang mampu mendorong ahli pasukan atau anggota organisasinya mencapai sesuatu matlamat adalah pemimpin berkualiti. ${ }^{55}$

Sehubungan dengan itu, Mohd. Affandi Hassan telah mengemukakan satu konsep pengurusan yang berkesan dan berkualiti yang dikenali sebagai 'Pengurusan Dengan Syura' (PDS). ${ }^{56}$ Melalui konsep PDS ini, seseorang akan mencapai tiga matlamat penting dalam sistem pengurusan organisasi iaitu: Pertama ialah penetapan falsafah pengurusan berdasarkan kitab al-Quran dan

52 Al-Qurțubī, Abū 'Abd Allāh, al-Jāmi' li Ahkām al-Qur'ān (Beirūt, Lubnān: Dār Ihyāa al-Turāth al-'Arabī, 2002), 161-162, ketika beliau menafsirkan ayat al-Quran 159, Surah Āli-'Imrān.

53 Abdullah Alwi Hj. Hassan, 'Al-Syura: Konsep dan Penerapannya dalam Organisasi dan Pentadbiran,' 75.

54 Abdul Ghafar Don, Berhanundin Abdullah dan Zulkiple Abd. Ghani, Dakwah dan Pengurusan Islam di Malaysia: Konsep dan Pelaksanaan, 35.

55 Ahmad Fadzli Yusof, Mengurus Kerja Berpasukan (Selangor: PTS Millenia Sdn. Bhd., 2007), 66-67.

56 Mohd Affandi Hassan, The Tawhidic Approach in Management and Public Administration: Concept, Principles and An Alternative Model, 70. 
Sunnah Rasulullah SAW. Kedua ialah keutamaan kepada lahirnya seseorang pemimpin atau pengurus yang mempunyai akhlak yang tinggi. Manakala matlamat ketiga pula ialah pelaksanaan perancangan sesebuah organisasi akan terjamin mencapai kejayaan bukan sahaja di dunia malah pada hari akhirat kelak. Konsep PDS ini dapat dilihat dengan lebih jelas melalui Rajah 1 berikut:

Rajah 1: Konsep 'Pengurusan Dengan Syura'.

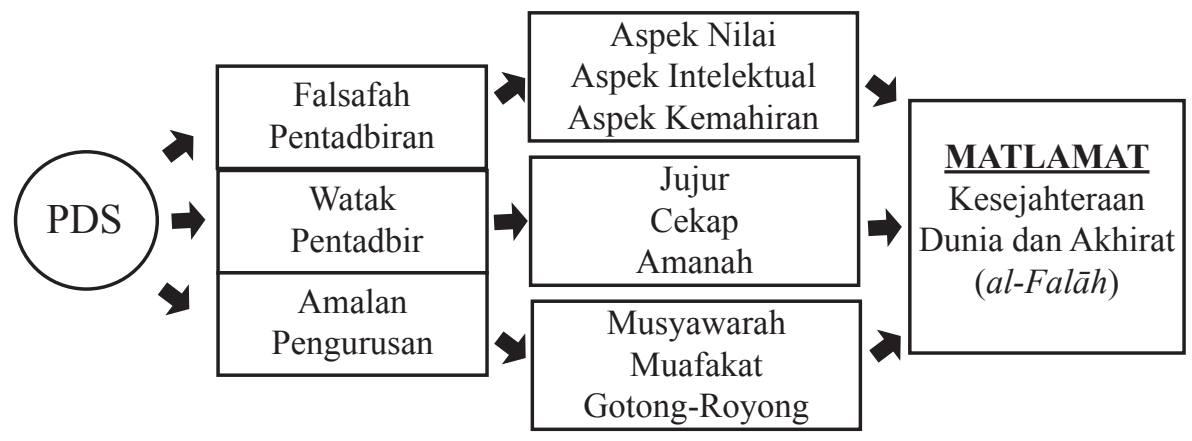

Sumber: Mohd. Affandi Hassan (1985). ${ }^{57}$

Secara tuntasnya, jika prinsip-prinsip yang dinyatakan di atas dapat difahami dan diamalkan oleh setiap warga dalam sesebuah organisasi sama ada sebagai pemimpin mahupun pengikut bawahan, nescaya tiada lagi wujud sebarang konflik organisasi. Hal ini demikian kerana setiap warganya telah pun bersepakat untuk mencapai matlamat yang sama iaitu memperoleh kejayaan yang hakiki (al-falāh).

\section{CADANGAN PEMANTAPAN SISTEM PENGURUSAN}

Sebagai kesimpulan penulisan artikel ini, dinyatakan secara ringkas beberapa cadangan bagi pemantapan sistem pengurusan dalam sesebuah organisasi agar ia berteraskan panduan Islam yang termaktub dalam kitab suci al-Quran dan Sunnah Rasulullah SAW, antaranya ialah:

(a) Pengurus organisasi hendaklah memastikan setiap kakitangan organisasi mempunyai visi serta matlamat kepercayaan yang berteraskan konsep

57 Mohd. Affandi Hassan, 'Pengurusan, Pentadbiran dan Kepimpinan dalam Pembinaan Tamadun Manusia,' Monograf Islamika III, cet. 1 (Kuala Lumpur: Persatuan Muzium Malaysia, 1985), 256. 
tawhīd $\bar{\imath}$ yang benar dan tidak menyeleweng daripada ajaran Islam sebenar. Malah, setiap kakitangan organisasi semestinya mempunyai kepercayaan yang jitu tentang keesaanAllah SWT serta Nabi Muhammad SAW adalah pesuruhNya.

(b) Memperbetulkan niat agar segala amalan hanya ikhlas beribadat kerana Allah SWT sama ada dalam melakukan tugas atau kerja yang diberikan dengan sebaik mungkin dan bukan hanya mementingkan ganjaran keduniaan semata-mata.

(c) Menanam sikap suka melakukan transformasi ke arah yang lebih baik dengan menjadikan setiap individu dalam organisasi sebagai role model atau idola yang perlu dicontohi oleh orang lain. Hal ini adalah kerana perubahan sangat perlu dilaksanakan kerana Imām al-Ghazzālī RA telah menegaskan bahawa individu yang cemerlang adalah seseorang yang sentiasa berubah ke arah yang lebih baik.

(d) Memupuk kesedaran kalangan pemimpin organisasi agar berperanan dalam memastikan segala urusan yang dilaksanakan sama ada peringkat kecil ataupun besar disempurnakan dengan sebaik mungkin. ${ }^{58}$ Individu itu sendiri perlu membangunkan jiwa rohani dan keperibadian akhlaknya serta disepadukan dengan unsur akal dan fizikalnya. ${ }^{59}$ Sekiranya seseorang pemimpin yang mentadbir sesuatu urusan tidak berakhlak mulia dan bermoral, sudah pasti akhirnya akan terlibat dengan gejala yang tidak diingini dan tidak lagi dipercayai. ${ }^{60}$

(e) Menerima tugasan sebagai satu amanah yang perlu ditunaikan dengan pelaksanaan yang bersungguh-sungguh, penuh akauntabiliti, tekun dan berintegriti yang merupakan kualiti penting bagi seseorang pemimpin. ${ }^{61}$ Malah, tugasan yang diberikan akan dilaksanakan dengan sesempurna mungkin mengikut kemampuan yang dimiliki seseorang.

58 Hasan Al-Banna Mohamed, 'Penekanan Akhlak dan Moral dalam Pembentukan Kepimpinan Islam Berkualiti,' Kertas kerja yang dibentangkan di Seminar Nasional Kepimpinan dan Politik dalam Era Perubahan dan Krisis: Dilema dan Cabaran Masyarakat Negara Membangun (Melaka, MITC Ayer Keroh, 24-25 Jun 2009), 28.

59 Ahmad Zabidi Abdul Razak, 'Pembangunan Organisasi Pendidikan yang Cemerlang Berasaskan Ciri-ciri Kepimpinan Islam,' Issue in Education (Masalah Pendidikan) 28 (2005): 105-115

60 Kouzes, J. M. dan Posner, B. Z., Creadibility: How Leaders Gain and Lose It, Why People Demand It (San Francisco: Jossey-Bass, 2011), 16-17.

${ }_{61}$ Mumtaz Begam Abdul Kadir dan Mohammed Sani Ibrahim, Integriti Peningkatan Kualiti Organisasi, 3. 
(f) Sentiasa mengamalkan budaya bermesyuarat (syura) dalam semua perkara sama ada isu yang kecil mahupun besar dengan penglibatan dan kerjasama daripada ahli kumpulan dalam sesebuah organisasi.

(g) Membudayakan amalan Islam yang menjadi Sunnah Rasulullah SAW iaitu sentiasa saling menegur antara satu sama lain sama ada pemimpin atau peringkat bawahan dengan konsep amar ma 'rūf dan nahī munkar.

\section{KESIMPULAN}

Jelaslah bahawa konsep pengurusan organisasi yang berkualiti sudah semestinya berlandaskan kepada ajaran Islam yang berteraskan dua sumber primer yang menjadi panduan sepanjang zaman iaitu kitab suci al-Quran dan Sunnah Rasulullah SAW. Konsep pengurusan tersebut membabitkan perhubungan yang tidak dapat dipisahkan antara Pencipta (Khäliq) dan makhlukNya serta hubungan sesama manusia dengan makhluk yang lain. Hal ini demikian kerana konsep pengurusan kualiti Islam bukan hanya menjurus kepada matlamat memberi kepuasan pelanggan, atau kesenangan hidup di dunia, atau mencapai matlamat sementara semata; bahkan hakikat tujuannya adalah mencapai mard̄atillāh (keredhaan) Allah SWT dalam segala urusan di dunia demi kebahagiaan di hari akhirat. Rentetan itu, pengurus atau pekerja sesebuah organisasi akan bersikap adil, berintegriti, akauntabiliti dan amanah melaksanakan kerja, cekal, berdaya saing dan berdisiplin sekiranya kelima-lima nilai pengurusan Islam yang dibincangkan (iaitu konsep tawhĭd $\bar{\imath}$, penerapan nilai kepimpinan yang beramanah, nilai amar ma 'rū $f$ dan nahī munkar, konsep keadilan ('adālah) dan prinsip pengurusan syura dijadikan amalan seharian bagi pemantapan sistem pengurusan organisasi berjalan lancar dan berkualiti.

\section{RUJUKAN}

Ab. Mumin Ab. Ghani, 'Sistem Pengurusan Islam: Tinjauan Menyeluruh dari Aspek Konsep,' dalam Dimensi Pengurusan Islam: Mengurus Kerja dan Mengurus Modal Insan, ed. Ab. Mumin Ab. Ghani dan Fadillah Mansor (Kuala Lumpur: Penerbit Universiti Malaya, 2006).

Abdul Ghafar Don, Berhanundin Abdullah dan Zulkiple Abd. Ghani, Dakwah dan Pengurusan Islam di Malaysia: Konsep dan Pelaksanaan (Bangi: Penerbit UKM, 2007).

Abdul Halim Ismail, 'Penerapan Nilai-Nilai Islam dalam Pentadbiran dan Pengurusan,' Jurnal Dakwah 3 (1987). 
Abdullah Alwi Hj. Hassan, 'Al-Shura: Konsep dan Penerapannya dalam Organisasi dan Pentadbiran,' Monograf Islamika III, cet. 1 (Kuala Lumpur: Persatuan Muzium Malaysia, 1985).

Abu Fahmi, Etika Beramar Makruf Nahi Mungkar (Jakarta: Gema Insani Press, 2001).

Abu al-'Ainain, J. J., The Principles of Management in Quran and Sunnah (Beirut: Al-Hilal Publishing Company, 2002).

Ahmad Fadzli Yusof, Mengurus Kerja Berpasukan (Selangor: PTS Millenia Sdn. Bhd., 2007).

Ahmad Ibrahim Abu Sin, Pengurusan dalam Islam, cet. ke-2 (Kuala Lumpur: Dewan Bahasa dan Pustaka, 1997).

Ahmad Zabidi Abdul Razak, 'Pembangunan Organisasi Pendidikan yang Cemerlang Berasaskan Ciri-ciri Kepimpinan Islam,' Issue in Education (Masalah Pendidikan) 28 (2005).

Al-Nawawi, Hadis Empat Puluh (Kuala Lumpur: Pustaka Aman Press, 1986).

Auni Haji Abdullah, Teras Utama Sistem Pengurusan Islam (Kuala Lumpur: Alam Raya Enterprise Sdn. Bhd., 2010).

Al-Bukhārī, Șaḥ̄ḥ al-Bukhārī (Beirūt: Dār Ibn Kathīr, 1998).

Al-Bukhārī, Ab̄̄ 'Abd Allāh Muhammad Ibn Ismā'îl Ibn Ibrāhīm Ibn alMughīrah Ibn Bardazibah, al-Adab al-Mufrad, vol. 1 (Beirūt: Dār alBasyā'ir al-Islāmiyyah, 1989).

Covey, S. R., The 7 Habits of Highly Effectively People: Powerful Lessons in Personal Change (New York: Simon and Schuster, 2013).

Fadzila Azni Ahmad, Kaedah Pengurusan Institusi-Institusi Pembangunan Berteraskan Islam di Malaysia (Shah Alam: Pusat Penerbitan Universiti (UPENA), 2010).

Hasan Al-Banna Mohamed, 'Penekanan Akhlak dan Moral dalam Pembentukan Kepimpinan Islam Berkualiti,' Pembentangan Kertas kerja Seminar Nasional - Kepimpinan dan Politik dalam Era Perubahan dan Krisis: Dilema dan Cabaran Masyarakat Negara Membangun (Melaka, MITC Ayer Keroh, 24-25 Jun 2009).

Hussin Mutalib, 'Islamic Leadership for Peaceful and Prosperous ASEAN,' Kertas seminar dibentangkan dalam International Conference on Islamic Leadership (ICIL 2011) (Kuala Lumpur, Hotel Royale Chulan, 4-5 Oktober 2011). 
Ibn Taymiyyah, Sheikhul Islām Taqī al-Dīn Abū al-'Abbās, al- 'Amr Bi alMa 'rūf wa Nahy 'an al-Munkar (Jeddah: al-Maktabah Dār al-Mujmatā', t.t.) (terj. Abu Fahmi, Etika Ber 'Amar Makruf Nahi Mungkar; Jakarta: Gema Insani Press, 2001).

IIhaamie Abdul Ghani Azmi, 'Pengurusan dari Perspektif Islam,' Jurnal Syariah 9/2 (2001): 85-102.

Kouzes, J. M. dan Posner, B. Z., Creadibility: How Leaders Gain and Lose It, Why People Demand It (San Francisco: Jossey-Bass, 1993).

Al-Kufī, Muhammad Ibn Abī Shaybah, Musannaf Ibn Abī Shaybah, vol. 5, no. hadīth 26275 (Riyāḍ: Maktabah al-Rusd, 1409H).

Mazilan Musa dan Shaikh Mohd Saifuddeen Shaikh Mohd Salleh, Quality Standard From the Islamic Perspective (Kuala Lumpur: IKIM, 2005).

Mohd Affandi Hassan, 'Pengurusan, Pentadbiran dan Kepimpinan dalam Pembinaan Tamadun Manusia,' Monograf Islamika III, cet. 1 (Kuala Lumpur: Persatuan Muzium Malaysia, 1985), 228-257.

Mohd Affandi Hassan, The Tawhidic Approach in Management and Public Administration: Concept, Principles and An Alternative Model (Kuala Lumpur: INTAN, 1992).

Mohd. Yusof Hj.Othman, Menjejak Kualiti Menjana Kecemerlangan (Kuala Lumpur: Dewan Bahasa dan Pustaka, 2000).

Morris, T., True Success, A New Philosophy of Excellence (New York: A Grossnet/Putnam Book, 1994).

Muhammad 'Abd al-Rauf, Management and Adminstration from an Islamic Perspective, $1^{\text {st }}$ ed. (Kuala Lumpur: Islamic Affairs Division, Prime Ministers Department, 1987).

MuhammadA.Al-Buraey, Administrative Development: An Islamic Perspective (London: K.P.I., 1985).

Muhammad A. Al-Buraey, 'Islamic Principles in the Management of An Organization: A Focus on Leading,' dalam Quality Standard from the Islamic Perspective, ed. Mazilan Musa dan Shaikh Mohd Saifuddeen Shaikh Mohd Salleh (Kuala Lumpur: IKIM, 2005).

Mumtaz Begam Abdul Kadir dan Mohammed Sani Ibrahim, Integriti Peningkatan Kualiti Organisasi (Kuala Lumpur: Utusan Publications \& Distributors Sdn. Bhd., 2009).

Muslim, Imām Abū Husayn Muslim Ibn al-Hajjāj Ibn Muslim al-Qushayrī alNaysābūrī, Șaḥ̄h Muslim (Riyāḍ: Dār al-Mughn̄̄, 1998). 
Nik Mustapha Nik Hassan, 'The Way Forward: Enchancing Islamic Leadership in the Globalized World,' Kertas kerja yang dibentangkan dalam seminar International Conference on Islamic Leadership (ICIL 2011) (Kuala Lumpur, Hotel Royale Chulan, 4-5 Oktober 2011).

Nor 'Azzah Kamri, 'Etika Pengurusan Islam dan Konvensional: Satu Analisis Perbandingan,' Jurnal Syariah 10/2 (2002): 43-66.

Panel Pengurusan YaPIEM, Pengurusan Islami: Menghayati Prinsip dan Nilai Qurani (Kuala Lumpur: Akademi Pengurusan YaPIEM, 2010).

Al-Qurțub̄̄, Abū 'Abd Allāh, al-Jāmi’ Li Aḥkām al-Qur'ān (Beirūt, Lubnan: Dār Ihyā' al-Turath al-'Arab̄i, 2002).

Shaharom TM Sulaiman, Pengurusan Islam dan Pembangunan Manusia (Batu Caves: Thinker's Library, 1997).

Sharifah Hayaati Syed Ismail al-Qudsy, 'Muafakat Tingkat Kualiti Kerja,' Berita Harian, 2 Julai 2011.

Syaikh Muhammad Ibn Șāliḥ al-'Utsaymin, Syarh al-Arba ’in al-Nawawiyyah, terj. Abu Ahsan Sirojuddin Hasan Bashri (Jakarta: Pustaka Ibnu Kathir, 2009).

Al-Ṭabaran̄̄, Abū al-Qāsim Sulayman Ibn Aḥmad, al-Mu’jam al-Saghīr, vol. 2, no. hadīth 980 (Beirūt: al-Maktab al-Islāmī, 1985).

Al-Tirmidhī, Abū 'Īsā Muhammad Ibn 'Īsā Ibn Surah, Sunan al-Tirmidhī, Taḥīiq: Dr. Bashar Awwad Maarof, vol. 4 (Beirūt, Dār al-Gharb alIslāmī, t.t.).

Siti Arni Basir, 'Pengurusan Organisasi dari Perspektif Islam: Satu Kajian Kes di Perbadanan Johor dan SAPURA Holdings,' Jurnal Syariah 1/9 (2001): 57-76.

Wan Liz Ozman Wan Omar, Pengurusan Islam Abad Ke-21: Revolusi Pengurusan untuk Keunggulan Sektor Awam dan Korporat (Kuala Lumpur: Utusan Publications \& Distributors Sdn. Bhd., 1997). 